\title{
Made to Connive: Revisioning Cinderella in a Music Video. From Disney to Arthur Pirozkhov: A Case Study ${ }^{1}$
}

\section{ABSTRACT}

The article focuses on the way in which music videos can subvert and refigure the message of literature and film. The author sets out to demonstrate how a music video entitled "Зацепила" by Arthur Pirozkhov (Aleksandr Revva) enters a dialogue with the recent Disney version of Cinderella by Kenneth Branagh (2015), which, in turn, is an attempt to do justice to Perrault's famous fairy tale. Starting out with Michèle Le Douff's comment on the limitations imposed upon women's intellectual freedom throughout the centuries, Filipczak applies the French philosopher's concept of "regulatory myth" to illustrate the impact of fairy tales and their Disney versions on the contemporary construction of femininity. In her analysis of Branagh's film Filipczak contends that its female protagonist is haunted by the spectre of the Victorian angel in the house which has come back with a vengeance in contemporary times despite Virginia Woolf's and her followers' attempts to annihilate it. Paradoxically, the music video, which is still marginalized in academia on account of its popular status, often offers a liberating deconstruction of regulatory myths. In the case in question, it allows the viewers to realize how their intellectual horizon is limited by the very stereotypes that inform the structure of Perrault's Cinderella. This makes viewers see popular culture in a different light and appreciate the explosive power of music videos which can combine an artistic message with a perceptive commentary on stereotypes masked by seductive glamour.

Keywords: Cinderella, music video, Kenneth Branagh, Arthur Pirozkhov.

1 This article was developed as part of the project entitled Word, Sound and Image: Intertextuality in Music Videos no. 2019/33/B/HS2/00131 financed by National Science Centre in Poland. 
In this article I would like to explore the afterlife of Perrault's Cinderella in the $21^{\text {st }} \mathrm{c}$. by referring to a Disney version of the fairy tale by Kenneth Branagh (2015) and its subversive parody in a music video in Russian entitled “Зацепила" by Arthur Pirozkhov (2019). A careful analysis of particular motifs makes it possible to reveal stereotypes implicit in the construction of femininity in the influential fairy tale. This, in turn, leads to the exposure of mechanisms that have resulted in the silencing of women as speaking subjects. In her seminal text The Sex of Knowing the feminist philosopher Michèle Le Dœuff mentions the power of regulatory myths which have rigorously controlled female access to intellectual life. While Le Dœuff discusses regulatory myths that used to restrict women in the past, she is far from optimistic when it comes to the female condition nowadays. This is what she sets out to confront in her book:

I will try to analyze all kinds of reluctance as residues with which we must be satisfied, and I hope at the same time to illuminate some of the many affirmations of women's lack of aptitude for knowledge, our nonaccess to reason, knowledge, sciences ... or the innumerable claims that for us such things are fairly indecent. (27)

My goal is to demonstrate how regulatory myths affect the constructions of femininity in media and thus prevent the full recovery of female identities. My contention is that while focusing on the particularities connected with individual female endeavors we cannot lose sight of the cultural backlash which sabotages these very endeavors. In order to prove my point I would like to focus on the rather unsettling return of fairy tale scenarios to film, and on how the Disneyification of fairy tales reinstates the "phantom" of the Victorian angel in the house whose death in each of us (women) Virginia Woolf so fervently encouraged and considered possible in her famous lecture "Professions for Women" (qtd. in Ellis 132). I am not encouraging a simplistic interpretation regarding sexism in media. In fact, I contend that some media can subvert the message of others, as is the case with "Зацепила."

The unabated popularity of fairy tales, which easily cross over into contemporary media, begs for critical attention. Harold Neemann states that "[i] $\mathrm{t}$ is precisely because fairy tale characters are types rather than individuals that they live forever" (43). The contention comes close to the Jungian concern with archetypes which are apparently eternal, but such a perspective prevents the reader from confronting the regulatory mechanisms which determine and circumscribe her existence in a particular social context. Jack Zipes, a distinguished authority on children's literature and folklore, brings together a myth and a fairy tale, thus revealing the implicit connection between both phenomena. Zipes's perspective on fairy 
tales was influenced by Susan Gilbert and Sandra Gubar's The Mad Woman in the Attic. Analyzing Disney's Snow White he makes the following point: "the film follows the classic 'sexist' narrative about the framing of women's life through a male discourse" (89). His comments on Disney films based on fairy tales are equally relevant for my argument: "despite their beauty and charm Sleeping Beauty and Cinderella in Disney versions are pale and pathetic, compared to the more demonic characters in the film" (89). In his book Disney Culture John Wills connects the beginnings of Disney's impact with the release of Snow White and the Seven Dwarfs (1937) which "preached traditional gender roles and old-fashioned morality" (5). Wills contends that Disney is much more than entertainment; Disney "exerts a powerful influence on our education, our values, our lifestyle choices" (5). In fact, the Disneyification of positive female characters in films constitutes a regulatory mechanism that curtails their independence, let alone their intellectual freedom.

It is interesting to examine Cinderella by Kenneth Branagh in light of the above. The director is known for drawing inspiration from popular Hollywood films that he watched as a boy. In fact, he brings populist appeal to his adaptations of Shakespeare (Crowl 10-11). In an interview with E Branagh explicitly states that his Cinderella "pays tribute to" Walt Disney's animated classic. Likewise, it transmits Disney's postVictorian code of values. The eponymous heroine is duly transformed into a contemporary equivalent of Coventry Patmore's "angel in the house," all her anger at her bad lot wiped out by the desire to please and to connive at her own reduction to a scapegoat. Interestingly, Patmore's long poem combines Cinderella features with the Victorian code, for example in a section entitled "The County Ball," which says: "But there danced she / Her brow more beautiful than morn, / Her sometime look of girlish state / Around her mouth the baby smile[.] Her ball-dress seem'd a breathing mist." According to Karin Hilck, Disney's heroine cum princess is "an epitome of femininity" signifying "girliness" and "cuteness" (52). This emphasizes attributes connected with appearance rather than agency. The same attributes had found their way into Patmore's poem. Thus Disney was Coventry Patmore's epigone.

The lead actress in Branagh's Cinderella, Lily James, was made to fit in with a Barbie doll image. Not only was she on a liquid diet throughout the film; her waist was also considerably slimmed, which elicited cautionary comments from media scholars such as Rebecca Hains, quoted in an online Guardian article by Tracy McVeigh:

This is an unrealistic beauty image, an exaggerated body type, and the fact that the actress then says, "oh yes, I was corseted so tightly I couldn't 
eat," I think is problematic. As is the plot. How brave is she really being? If she doesn't have a prince, then she stays and accepts the abuse.

In fact, Lily James's image quickly fed into the new Mattel dolls such as Disney Royal Ball Cinderella Doll, which is meant to "enchant" girls. The description of her finery draws attention to "a coordinating bodice" ("Disney Royal Ball Cinderella Doll"). The film and doll industries join hands in selling, or "peddling," as Hains puts it, the coveted image to millions of girls who are encouraged to dream their lives away instead of making use of their own minds. Young women are forever arrested at the stage of development permeated with what Wills calls "childlike simplicity and sentimentality" (10). Almost disembodied, Ella in Branagh's film becomes an illusion of timeless youth, unlike her stepmother, an experienced, elegant woman who is avid for success and, therefore, repulsive. Ella's stepmother belongs in the category that Tomasz Fisiak describes as Gothic female tyrants who "often adopt controversial methods to succeed in the unfriendly phallocentric environment" (Fisiak 158).

When the prince eventually finds her, Cinderella is locked in the attic of her former home, a damsel in distress in her stepmother's Gothic scenario. True, she liberates herself by means of her voice, that is, by singing, which attracts the prince's attention. One might hear echoes of The Song of Songs in the scene because in the biblical text the voice is that attribute of the beloved that her lover yearns for when he says: "let me hear thy voice; for sweet is thy voice, and thy countenance is comely" (King James Bible 2:14). These two elements characterizing a young woman in love were the only ones that the rigid code of fairy tales accepted. Dunn and Larson contend that singing and music were traditionally regarded as the only safe outlet for female self-expression and the only way to navigate the gap between domestic privacy and public space in women's case (20-21).

Apart from the above, in Branagh's film, Cinderella's agency is transferred on to the animals that help her achieve her goal. It is not only the fact of her being driven in a carriage by the crew recruited from animals at the fairy godmother's bidding. This continues the Disney tradition in which Snow White was able to converse with forest creatures that protected her from danger (Wills 10). In the scene in which Ella reveals herself by singing, the mice help her by unlatching and pushing open the window so that the prince might hear her. Animals facilitate Ella's revealing herself to the prince not only as his actual but also as his potential beloved. Even when Cinderella first meets the prince in the forest she distracts his attention from the hunt because her horse carries her away, and the prince is worried that she might fall off. Thus whatever initiative Cinderella might have is subtly diverted on to animals with her being left almost unaware of 
the fact that she is pursuing her own desire. Thus, any agency on her part either goes underground and is thwarted, or it is shouldered by friendly creatures. It must be clear to the audience that she does not pursue her own desire, but is acted upon rather than acting.

The Christian moral framework in the respective versions of Cinderella by Perrault and the Grimm brothers was analyzed by Cyrille François in “'Cendrillon' and 'Aschenputtel': Different Voices, Different Projects, Different Cultures." The question is to what extent Perrault's and the Grimm Brothers' constructions of Cinderella are secular echoes of passages about the Virgin Mary in the Gospel of Luke (1:26-55), that is, the excerpts including Annunciation, Mary's consent to being elected and her joyous song, i.e. the Magnificat. Branagh may have been totally oblivious to the Christian framework of the story which lingers on as a trace in earlier Disney versions. Still, he tried to shift emphasis from the patriarchal framework to the female voice by turning the fairy godmother into the narrator. The result was that the patriarchal message was wrapped up in ostensibly female focalization to make it easier for young women to accept. As Angela Carter revealed in her rewriting of Cinderella, the fairy godmother may well be the ghost of Cinderella's dead mother (Wiley 93). In Carter's versions of the story, the mother is first seen as the one whose sacrifice is necessary for the daughter's success, which is exposed as problematic. Then she is the one who offers her daughter a carriage and a red dress, that is, freedom of movement and the right to follow her desire (Wiley 97). In Branagh's film the conventionally pink dress that Cinderella inherited from her mother is given a new blue color by the fairy godmother. Blue is the Marian color in many Catholic representations of the Virgin Mary, but the statue has been reduced to a doll in the secular story of female salvation.

Cinderella is unique in her virtue, perfection and beauty. Also, she is the one who receives the message of supernatural choice and welcomes it like Mary. While she is the only one to be treated like that, her fate sets up a model for imitation. All girls are supposed to identify with her, face humiliations patiently and cope with injustice until they are (or are not) rewarded. Even Cinderella's singing in Branagh's rendition of the tale fits with the expressiveness of women in the Bible. Mary sings the Magnificat in the scene of Annunciation, and through this she identifies with women who praised God by singing. Cinderella sings when her future bridegroom is near her house. As stated earlier this brings to mind The Song of Songs. In this most unusual book of the Bible and yet one of the most cherished texts in Judaism most of the narrative is focalized and shared by the powerful female voice of a country girl in love with the king. This is certainly a scenario that anticipates Cinderella. The sunburnt heroine of a Hebrew pastoral is much more appreciated by the 
king (her lover) than the pale and conventional "daughters of Jerusalem," that is, women from the court (Landy 146-47). The difference is that in the biblical text the beloved is much more active, restless and demanding in the pursuit of her erotic desire. She is certainly endowed with agency because she actively voices and fulfills her erotic potential. In contrast, Cinderella is subdued, and she relies on others to save her. What happens to female agency when Cinderella is translated into a social phenomenon? Amy M. Davis contends that "Disney is the primary curator of America's fairy tale and folklore" (183), but fairy tales can easily shape expectations and fashion. The critic discusses the popularity of sumptuous fairy tale weddings and draws attention to the way in which the Cinderella scenario not only fed into the wedding industry, but also became a bridal version of the American dream, which had its opulent realization in the life of Grace Kelly, "a little girl from Philadelphia," as the newspaper headlines condescendingly put it (Davis 180).

Let me now discuss the music video starring Aleksandr Revva (whose pseudonym is Arthur Pirozkhov), an actor from the troubled area of Donetsk claimed by Russia and the Ukraine. The title "Зацепила" literally means "she accosted me," but it was more ambiguously translated into English as "Caught," which does not reveal who caught whom, or who is caught by what. The video can be classified as a parodic appropriation or rewriting of the main elements in Branagh's Cinderella. I am referring to and modifying one of the categories of intertextuality in media analyzed by Ott and Cameron, who identify a "parodic allusion," as "a stylistic device in which one text incorporates a caricature of another" (436). The similarities between the video and Branagh's Cinderella include dress code, gestures and splendor of space that is meant to entice and mislead unwary female viewers. The deconstruction of culturally accepted symbolism is actually introduced through music. According to Małgorzata Grajter, a music theorist,

the song by Pirozkhov opens with a quotation from "La valse de l'amour" from the Patrick Doyle soundtrack to the film Cinderella, in which the original polyphonic texture is reduced to just one melodic voice and a symphony orchestra is replaced by synthetic strings. The rhythm of a waltz, which was traditionally used in the context of ball (at least, since Hector Berlioz's Symphonie fantastique), is then put in a stark contrast with modern techno music.

Like the representatives of the prince in Branagh's film, the protagonist (Pirozkhov) in the music video has to face a line of women queuing in order to try on a crystal slipper. He does not hide his exhaustion with what seems to be a futile task, and eventually asks his majordomo to encourage the guests 
to dance. This is when a beautiful and unescorted woman appears. Female transformation is central to the space of Disney castles, as Martha Bayless contends (50). Their sumptuous interior is echoed in Pirozkhov's video. But the transformation is not what the viewer might expect. Five minutes before twelve the most attractive woman tries to leave the ball but she is followed by the prince who kisses her, and this is when the clock strikes twelve.

From a slim, ethereal beauty, the woman of the protagonist's dreams is suddenly transformed into a middle aged and "plus size" lady. The prince is utterly horrified when he notices whom he has kissed. In British Women's Cinema Imelda Whelehan contends that film is just one medium that has favored youthful women. Older women who are underrepresented in mainstream culture may be seen as liberated from the "prison-house" of femininity or rendered invisible not only to the desiring male eye, but also to the eye of a feminist critic (170). The sudden invasion of middle age in a favored heroine is what a fairy tale cannot accommodate, so it is in the power of Cinderella to make use of the allotted time wisely. Pirozkhov's video exposes cultural chronophobia implicit in the tale. In her book entitled Narratology Mieke Bal uses the term chronophobia when referring to the merciless king from Arabian Nights. The king kills all the virgins after the first night until Scheherazade seduces him into a different kind of temporality, i.e. the temporality of the story, and thus she gains time for her own life. Bal states that "the king suffers from chronophobia, the fear that time is enemy's gain, and from gynophobia, the fear that women have life and desire of their own, hence a subjectivity" (67). Chronophobia is very much at stake in Cinderella where the fairy godmother can suspend all the physical laws except the flow of time. It is due to this flaw that ordinary reality returns. In Branagh's film we see the golden carriage crash against the bushes as it is being transformed into the pumpkin again. As the fairy tale demands the heroine is spared death or mutilation, and finds her way home drenched with rain but radiant.

How does Pirozkhov's video come into this? When the clock strikes twelve as the unknown princess is being kissed, time comes back with a vengeance, and the prince faces a "plus size" female body. Horrified by his nightmarish vision of beauty turned into what he cannot accept, the protagonist of the video decides to fit the crystal shoe on to the woman's foot, and a miracle takes place; she goes back to her former self, much to his relief. But when the slipper is removed or even partly taken off, an unwanted change sets in. The music video draws attention to inevitable changes in female corporeality as the prince imagines his future with Cinderella at his side, drinking champagne, while their children feast on enormous cakes with cream. In contrast, he imagines himself as perpetually young and changeless. This is a sideswipe at male narcissism. 
Revva (Pirozkhov) is, first of all, a comic actor. He deals with his problem in a witty way. He glues and straps the magic slippers on to his dancing partner's feet, as a result of which the dance goes on without any further obstacles. It is pertinent to note that a similar practice occurs in the fashion world. Danica Lo states in Glamour that Marc Jacobs had the models' feet glued into their shoes at the spring Vuitton fashion show. There is a serious message in the collective jest that is offered by way of conclusion. The slipper is a symbolic tool pointing to the inevitable connection between successful womanhood and youth. Its message is "Thou shall not age." Swarovski crystal used in Branagh's Cinderella has migrated into the music video in a debased form. The woman is encased in a particular construction that prevents her from changing at all costs; she has frozen back into an eternally young Galatea because of her Pygmalion's chronophobia.

Much debate took place among scholars about the material that the famous slipper was made of. Numerous versions of the fairy tale testify to the variety of ingenious choices. Comparing Bruno Bettelheim's analysis of the Brothers Grimm Cinderella and Arthur Boyd Houghton's insight into one of the Oriental versions of the story, Allan Life draws attention to the fact that in the Grimms' version the protagonist's slippers are made of gold, which makes Bettelheim compare the ring ceremony and the vaginal symbolism of the slipper which fits on a phallic foot (162). The Freudian interpretation has been in vogue ever since Alan Dundes followed some of his predecessors in refuting the hypothesis about a possible mistranslation of vair (fur) into verre in Perrault's version, arguing that "glass is an appropriate symbol of virginity ... once broken it cannot be repaired" (139). The traces of Mariolatry in Perrault's version of the story would explain Dundes's emphasis on the significance of Cinderella's virginity which is "guaranteed" because the glass slipper perfectly fits only her foot. The virginity fetish has persisted, and this is exactly what Pirozkhov's video tackles and transforms.

Before unpacking my point, I would like to focus on a scene from Branagh's film, which makes use of crystal, a symbol of purity and perfection in Christian religion. The stepmother finds and appropriates Cinderella's other shoe hidden in the attic. Then she confronts her stepdaughter and tries to force her to comply with a deal that presupposes the stepmother's share in the power of the future couple. When Cinderella refuses to make the deal, arguing that she did not manage to protect her father from devious scheming, but she will protect the prince, the stepmother crashes the remaining slipper against the door frame, symbolically preventing Cinderella's exit from the attic where she should waste away, potentially into madness, as well as old age. 
In Pirozkhov's video the chronology of events from the fairy tale is reversed. When the prince puts the slipper on his partner's foot and finds out that she is young and beautiful, he takes the slipper off her foot again. But to his horror, her youth and beauty are inextricably bound up with wearing the slipper. In his imagination Pirozkhov's prince notices the fabled golden carriage in the middle of the ballroom. The fairy tale turned into a nightmare has now invaded his palace. His beloved is shown next to him in the carriage, both of them encased in the scenario that unfolds relentlessly. The woman eventually drops her slipper on the floor through the door of the carriage and destroys it. Only the fragments remain as the prince's fetish dismally ruins his prospective of conjugal happiness. The scenes from Branagh's and Pirozkhov's versions are definitely related. Just like the stepmother ruined Cinderella's dream by smashing the slipper against the door, so does the prince's monstrous beloved send his dream into smithereens. In both scenes the door-between the attic and the rest of the household or the carriage and the ballroom-operates as a liminal boundary between the worlds of reality and fantasy respectively. Pirozkhov's partner shows her own agency in the act of smashing the crystal slipper of male illusions connected with the perfection of perpetually young female body. But as a patriarchal (and tongue in cheek) fairy tale might have it, the slipper from Pirozkhov's video miraculously comes together again. That was just the prince's bad dream, which he shakes off and sets about the task of gluing and strapping the slippers on to the lady's feet. The fetish from Perrault and Disney has been exposed, but also revisioned as a different kind of fetish: the denial of change, old age and death.

While music videos often recycle stereotypes they can also explode them through a powerful combination of text, sound and image fused into one entity. “Зацепила" pokes fun at the Disneyified construction of femininity, "[b]ound up with expectations of body type, sexuality, and male rescue" (Wills 122-23). The fantasy of "happily ever after" is smashed like a crystal slipper as "the realities of life" intrude upon the imaginary ballroom in the middle of which the golden carriage is placed. At the same time, the video shows that Disney's message is inexorably resistant to change. This confirms the connection between fairy tales and regulatory myths which relentlessly reassert their sway in patriarchal culture. The jubilation at the end of Pirozkhov's video shows that regulatory myth is alive and well despite the attempts to expose its oppressive character. Branagh's Cinderella has been appropriated and parodied in "Caught" as a version for adults. The princess has changed physically after giving birth to two children. Family life is incompatible with fantasy unless the family members take a break from routine in Disneyland. Despite the efforts of the Disney studio to modernize and update its heroines, Branagh's 
Cinderella falls back on the old message and plays it safe, as Pirozkhov's video reminds us. Far from being consigned to oblivion, Coventry Patmore has the last word: “O queen, awake to thy renown, / Require what 'tis our wealth to give, / And comprehend and wear the crown / Of thy despised prerogative!”

\section{Works Cited}

Bal, Mieke. Narratology. Introduction to the Theory of Narrative. Fourth Edition. Toronto: U of Toronto P, 2017. Print.

Bayless, Martha. "Disney's Castles and the Work of the Medieval in the Magic Kingdom." The Disney Middle Ages: A Fairy-Tale and the Fantasy Past. Ed. Tison Pugh and Susan Aronstein. New York: Palgrave Macmillan, 2012. 39-75. Print. https://doi.org/10.1057/9781137066923_3

Crowl, Samuel. The Films of Kenneth Branagh. Westport, CT: Praeger, 2006. Print.

Davis, Amy M. Discussing Disney. Bloomington: Indiana UP, 2019. Print. https://doi.org/10.2307/j.ctvqc6k2q

“Disney Royal Ball Cinderella Doll.” Amazon.com. Web. 23 Feb. 2020.

Dundes, Alan. Folklore Matters. Knoxville: U of Tennessee P, 1989. Print.

Dunn, Leslie C., and Katherine R. Larson. Gender and Song in Early Modern England. London: Routledge, 2016. Print. https://doi. org/10.4324/9781315583952

Ellis, Jeanne. "A Bodily Metaphorics of Unsettlement." Neo-Victorian Gothic: Horror, Violence and Degeneration in the Re-Imagined Nineteenth Century. Ed. Marie-Luise Kohlke and Christian Gutleben. Amsterdam: Rodopi, 2012. 123-45. Print. Web. 22 Apr. 2020. https:// doi.org/10.1163/9789401208963_006

Fisiak, Tomasz. She- $(d)$ evils? The Construction of a Female Tyrant as a Cultural Critique. Berlin: Peter Lang, 2020. Print.

François, Cyrille. “'Cendrillon' and 'Aschenputtel': Different Voices, Different Projects, Different Cultures." Cinderella across Cultures: New Directions and Interdisciplinary Perspectives. Ed. Martine Hennard Dutheil de la Rochère. Detroit: Wayne State UP, 2016. Print. Web. 22 Apr. 2020.

Grajter, Małgorzata. Personal e-mail communication with the author. 13 May 2019.

Hilck, Karin. "The Space Community and the Princess: Reworking the American Space Programme's Public Image From Miss NASA to Princess Leia." A Galaxy Here and Now: Historical and Cultural Readings of Star Wars. Ed. Peter W. Lee. Jefferson, NC: McFarland, 2016. 33-61. Print. 
Holy Bible: King James Version. New York: American Bible Society, 1980. Print.

Landy, Francis. Paradoxes of Paradise. Identity and Difference in the Song of Songs. Sheffield: Almond P, 1983. Print.

Le Douff, Michèle. The Sex of Knowing. Trans. Kathryn Hamer and Lorraine Code. New York and London: Routledge, 2003. Print.

Life, Allan. "Scheherazade's Special Artist: Arthur Boyd Houghton." Haunted Texts: Studies in Pre-Raphaelitism in Honour of William E. Fredeman. Ed. David Latham. Toronto: U of Toronto P, 2003. 14576. Print.

Lo, Danica. "Marc Jacobs Glued Models' Feet Into Their Shoes at the Spring Vuitton Show." Glamour.com. Glamour 19 Jan. 2012. Web. 13 Apr. 2020.

McVeigh, Tracy. "Kenneth Branagh's Corseted Cinderella Fails the Frozen Test, Say Critics.” Theguardian.com. Guardian 21 Mar. 2015. Web. 7 Apr. 2020.

Neemann, Harold. Piercing the Magic Veil: Toward a Theory of the Conte. Tübingen: Gunter NarrVerlag, 1999. Print.

Ott, Brian, and Walter Cameron. "Intertextuality: Interpretive Practice and Textual Strategy." Critical Studies in Media Communication 17.4 (December 2000): 429-46. Print. https://doi.org/10.1080/ 15295030009388412

Patmore, Coventry. The Angel in the House. Gutenberg.org. Project Gutenberg. Web. 22 Apr. 2020.

Whelehan, Imelda. "Not to be Looked at: Older Women in Recent British Cinema." British Women's Cinema. Ed. Melanie Bell and Melanie Williams. Abingdon: Routledge, 2009. 170-83. Print.

Wiley, Jeanne. "Rewriting Cinderella: Envisioning the Empowering Mother-Daughter Romance." Mothers and Daughters: Connection, Empowerment, and Transformation. Ed. Andrea O'Reilly and Sharon Abbey. Lanham: Rowman \& Littlefield, 2000. 91-102. Print.

Wills, John. Disney Culture. New Brunswick: Rutgers UP, 2017. Print. https://doi.org/10.36019/9780813583341

Zipes, Jack. Fairy Tale as Myth/Myth as Fairy Tale. Lexington: U of Kentucky P, 2013. Print.

\section{Dorota Filipczak is Head of Department of Canadian,} Intermedial and Postcolonial Studies in the Institute of English Studies, University of Lodz. Her publications include The Malcolm Lowry Review (Wilfrid Laurier University, Ontario, 1998-99), Unberoic Heroines: The Portrayal of Women in the Writings of Margaret Laurence 
(Eódź UP, 2007), "Gender and Space in "The Albanian Virgin"” in Alice Munro: Understanding, Adapting and Teaching, ed. Mirosława Buchholtz (Springer, 2016), Brian Moore's Eponymous Heroines: Representations of Women and Authorial Boundaries (Peter Lang, 2018) and "The Disavowal of the Female Knower': Reading Literature in the Light of Pamela Sue Anderson's Project on Vulnerability" in Angelaki 25.1-2 (2020). She has published seven books of poetry, and is a member of the Association of Polish Writers. She is currently in charge of the project Word, Sound and Image: Intertextuality in Music Videos no. 2019/33/B/HS2/00131 financed by National Science Centre in Poland.

ORCID: 0000-0001-5419-4718

dorota.filipczak@uni.|lodz.pl 